\title{
PERKEMBANGAN WISATA BELANJA “OLEH-OLEH MAKANAN" DI KOTA MALANG
}

\author{
Nonny Aji Sunaryo \\ Universitas Negeri Malang \\ Email: nonny.sunaryo.ft@um.ac.id \\ I Nyoman Darma Putra \\ Universitas Udayana \\ Email: idarmaputra@yahoo.com \\ Made Heny Urmila Dewi \\ Universitas Udayana \\ Email: henyurmila@gmail.com
}

\begin{abstract}
Shopping currently recognize as a tourism attraction. Malang is one of shopping tourism destinations in Indonesia, tourist go to Malang for bought food souvenirs. This study is aimed to find out the development of food souvenirs in Malang. This study uses a qualitative method. The results of this study indicate that the development of food shopping tourism has gone quickly within these past four years, starting from 2014 to 2018. This development is not only seen by the number of food souvenirs businesses, but also the variety of food souvenirs that are available in the market. There are 9 types of food souvenirs in Malang.
\end{abstract}

Keywords: Shopping Tourism, Souvenirs, Food, Malang City

\section{Pendahuluan}

Kota Malang dikenal sebagai salah satu destinasi favorit tujuan wisatawan domestik, pada perkembangannya wisata belanja menjadi salah satu potensi daya tarik wisata. Wisata belanja di Kota Malang secara intern muncul karena ada pola pertumbuhan sektor lain yang keberadaanya mendukung pariwisata yaitu sektor industri mikro gastronomi olahan holtikultura berupa "oleh-oleh makanan" khas Kota Malang (Renstra Disbudpar Kota Malang, 2013), selain itu secara ekstern 
ketertarikan atau minat wisatawan terhadap wisata belanja, memang juga terus bertumbuh, karena menurut wisatawan berbelanja khususnya "oleh-oleh makanan" mempunyai kedudukan penting dalam wisata yang mereka lakukan, yaitu sebagai bagian dari pengalaman liburan atau kenangan yang bisa dibawa pulang (Mossberg, 2007).

Unsur kenangan dalam berwisata di Indonesia termasuk dalam Sapta Pesona, yaitu konsep sadar wisata yang berhubungan dengan dukungan dan peran masyarakat sebagai tuan rumah, untuk menciptakan lingkungan dan suasana kondusif, dengan mewujudkan unsur aman, tertib, bersih, sejuk, indah, ramah dan kenangan. Apabila ketujuh unsur tersebut diwujudkan, hal itu akan mendukung berkembangnya kepariwisataan di suatu destinasi sehingga mendorong minat wisatawan untuk berkunjung (Pedoman Pokdarwis, 2012). Kendati penting, ternyata saat ini studi tentang hal tersebut di Indonesia masih sangat minim, padahal keberadaannya bisa menjadi dasar untuk mengembangkan suatau destinasi wisata, adanya penelitian ditujukan untuk meminimalisir masalah tersebut dengan mendiskripsikan bagaimana perkembangan wisata belanja "oleh-oleh makanan" di Indonesia khususnya di Kota Malang.

\section{Landasan Teori dan Konsep}

\section{Teori}

Studi ini menggunakan teori wisata belanja yang dikemukakan oleh Timothy (2005), menurutnya teori wisata belanja (shopping tourism) adalah teori mengenai kegiatan wisata yang terkait dengan belanja barang atau jasa di sebuah destinasi wisata. Timothy (2005) dalam bukunya berjudul "Shopping Tourism, Retailing, and Leisure", memaparkan belanja adalah salah satu kegiatan yang paling umum dan menyenangkan yang dilakukan oleh orang-orang yang sedang berlibur dan telah menjadi motivasi dasar untuk bepergian, hal tersebut dipengaruhi munculnya 
sistem transportasi yang lebih efisien, peningkatan teknologi, dan penggunaan kartu kredit yang meluas, sehingga dalam banyak kasus, belanja menjadi daya tarik utama, sehingga seseorang dapat melakukan perjalanan lebih jauh ke suatu tempat hanya untuk berbelanja.

\section{Konsep}

Wisata belanja yang dimaksud adalah kegiatan perjalanan yang dilakukan seseorang dalam rangka membeli barang ataupun jasa di suatu lokasi. "Oleh-oleh" adalah barang yang dibawa seseorang dari bepergian sebagai bukti/kenangan untuk diri sendiri atau buah tangan/sovenir untuk orang lain. Makanan, yang dimaksud dengan adalah barang/produk yang dapat dikonsumsi (dikunyah dan ditelan) oleh manusia. Sehingga dapat disimpulkan konsep wisata belanja "oleh-oleh makanan" yang dimaksud dalam penelitian ini adalah, kegiatan wisata atau perjalanan yang dilakukan dalam rangka membeli barang yang dapat dikonsumsi manusia yaitu makanan, untuk dibawa pulang ke asalnya oleh wisatawan nusantara sebagai bukti/kenangan yang mereka nikmati sendiri atau sebagai buah tangan/sovenir untuk orang lain.

\section{Metode Penelitian}

Penelitian ini dilakukan dengan menggunakan metode deskriptif kualitatif sehingga peneliti merupakan istrumen primer dalam teknik pengumpulan data berupa observasi, wawancara, dan dokumentasi. Lokasi penelitian adalah di Kota Malang, khususnya di wilayah Kecamatan Klojen, dan Kecamatan Blimbing, pemilihan lokasi mengacu pada Peraturan Wali Kota Malang No. 34 tahun 2014 tentang Rencana Induk Pengembangan Pariwisata Daerah tentang arah kebijakan pembangunan daya tarik wisata, meliputi kebijakan pengembangan kawasan. Wilayah Kecamatan Klojen, dan Blimbing merupakan kawasan pusat wisata, perbelanjaan, perdagangan, dan kuliner. Penelitian ini dilakukan mulai Februari hingga Juni 2018. 
Sumber data atau informan penelitian ini meliputi Kepala Subbag Perencanaan Usaha Mikro Dinas Koeperasi dan UKM Kota Malang, Kepala Seksi Pembinaan dan Pengembangan Industri Makanan Minuman Dinas Perindustrian Kota Malang, Kepala Bidang Ekonomi Kreatif Dinas Pariwisata Kota Malang, Ketua Kelompok Sadar Wisata (POKDARWIS) sentra produksi “Oleh-Oleh Makanan" Sanan Malang, pelaku usaha, dan konsumen "oleh-oleh makanan". Data yang diperoleh diolah secara manual, dengan cara diidentifikasi, dipilah, dikelompokkan, dianalisis, diinterpretasi dan hasilnya dilaporkan dalam artikel ini.

\section{Hasil dan Pembahasan}

Rencana Strategis Dinas Kebudayaan dan Pariwisata (Renstra Disbudpar) Tahun 2013-2018 (2013:41) Kota Malang, menyebutkan bahwa untuk mendukung pembangunan pariwisata, pengembangan kepariwisataan di Kota Malang diarahkan ke pariwisata perkotaan, dan wisata belanja menjadi sektor yang diunggulkan. Kekuatan lain yang membuat Kota Malang berkesempatan menjadi destinasi wisata belanja adalah lokasi Kota Malang yang strategis, karena terletak diantara Kabupaten Malang dan Kota Batu yang juga populer pariwisatanya. Dibandingkan keduanya Kota Malang lebih unggul dalam persediaan fasilitas pariwisata, termasuk sarana perbelanjaan. Hal tersebut selanjutnya menarik wisatawan untuk pergi berbelanja di Kota Malang sebagaimana pernyataan saaat wawancara oleh Kepala Seksi Pemasaran Bidang Ekonomi Kreatif Dinas Kebudayaan dan Pariwisata Kota Malang, Artis Swastini.

Dalam Renstra Disbudpar 2013-2018 disebutkan bahwa Kota Malang merupakan daerah penopang (feeder) bagi aktifitas wisata di Kawasan Malang Raya (Kota Malang, Kabupaten Malang, dan Kota Batu) yaitu sebagai penyedia fasilitas pariwisata diantaranya jasa akomodasi, kuliner, dan pusat perdagangan. Menurut Arvi (wawancara Maret 2018) salah satu wisatawan asal Bandung menyatakan lokasi Kota Malang yang berada di tengah-tengah menjadi alasan baginya untuk 
tinggal sebelum mengunjungi destinasi lainnya yaitu Kota Batu dan pantai di Kabupaten Malang. Sependapat dengan Arvi, wisatawan dari Jakarta yaitu Amir (Wawancara 10 Maret 2018) dirinya dan keluarga memilih beristirahat di Kota Malang dan memanfaatkan waktunya untuk berbelanja, sebelum keesokan harinya mengunjungi pantai di Kabupaten Malang. Berdasarkan pernyataan tersebut dapat diartikan Kota Malang juga sebagai destinasi transit atau sebagai daerah penopang (feeder). Selain tinggal tentu wisatawan melakukan kegiatan-kegiatan lain salah satunya adalah berbelanja. Hal tersebut mendukung pernyataan Timothy (2005), bahwa aktivitas belanja merupakan salah satu aktivitas rekreasi yang menyenangkan.

Pada perkembanganya wisata belanja sebaiknya menurut Hasan (2015) yaitu harus diciptakan dengan dukungan penuh dari pengusaha dan pemerintah setempat, di Kota Malang seluruh arah dan dinamika pembangunan dititik beratkan pada 3 sektor termasuk didalamnya sektor gastronomi dan kepariwisatan (Renstra, 2013). Di Kota Malang salah satu potensi yang dapat mendukung wisata belanja adalah makanan. Sejak lama apel dan tempe adalah makanan lokal khas, pada perkembanganya keduanya diolah agar lebih lama daya tahannya dengan dibuat menjadi keripik, hal tersebut jugalah yang membuat makanan tersebut dapat menjadi "oleh-oleh makanan". Produk "oleh-oleh makanan" yang diharapkan wisatawan adalah makanan lokal yang mempunyai kekhasan. Menurut Nanuk (wawancara 11 Maret 2018) wisatawan asal Aceh mengatakan, ketika berwisata kita ingin merasakan bagaimana makanan yang ada di tempat yang kita kunjungi, dan membawa pulang makanan yang bisa dibawa pulang sebagai "oleh-oleh".

Makanan dapat menjadi ikon suatu destinasi pariwisata (Putra, 2014), karena dianggap sebagai barang yang dapat mencerminkan perbedaan budaya dan gaya hidup masing-masing tempat, hal tersebut kemudian menjadi daya tarik wisatawan untuk datang berkunjung. Pernyataan tersebut didukung Bjork (2016) bahwa ada 
jenis wisatawan yang menginginkan pengalaman makan makanan khas atau ikonik sebagai tujuan mereka berwisata, wisatawan seperti itu selanjutnya disebut sebagai wisatawan foodist. Keripik tempe sejak lama memang sudah menjadi andalan "oleholeh makanan" asal Kota Malang sebagaimana dikatakan Hapiz (2015) bahwa keripik tempe merupakan ikon “oleh-oleh makanan” Kota Malang.

Keripik tempe dianggap sebagai ikon dan menguasai pasar "oleh-oleh makanan" di Kota Malang, tidak ada literatur pasti yang menyebutkan sejak kapan keripik tempe ini menjadi terkenal. Menurut Ivan Kuncoro (Wawancara 5 Maret 2018) sebagai pembentuk dan ketua paguyuban pengerajin tempe dan keripik tempe sanan menyatakan bahwa sejak tahun 1980an sudah ada pengerajin tempe, lama kelamaan banyak yang membuat tempe sehingga stok berlebih lalu muncul ide untuk mengawetkan dengan cara mengolah tempe menjadi keripik, itulah yang menjadi cikal bakal adanya kreasi keripik tempe yang terkenal hingga saat ini. Dalam kutipan artikel berjudul metamorfosis sebuah sentra keripik tempe (Peluang usaha, 2010), pengerajin keripik tempe mulai bermunculan di awal tahun 1990-an ada 3 pengerajin yang memproduksi dan menjual keripik tempe, baru sekitar tahun 2000-an, pengrajin keripik mulai bertambah.

Saat ini keadaan di lapangan berdasarkan hasil penelitian, pesona keripik tempe khususnya rasa original memang masih menarik wisatawan untuk membeli dan menjadikan keripik tempe "oleh-oleh makanan" utama untuk dibawa pulang. Namun seiring dengan perkembangan zaman, muncul diversifikasi produk, jika dulu rasa keripik tempe hanya original, sekarang diberi tambahan bumbu tabur rasa-rasa seperti rasa balado, keju, dll. Hal tersebut dikarenakan pengaruh struktur pasar sebagaimana hasil penelitian Widyasari (2012) bahwa struktur pasar di Kampung Sanan merupakan pasar persaingan monopolistik dimana tidak ada hambatan untuk suatu perusahaan atau pemain baru untuk memasuki pasar. Hal itu mendorong produsen untuk membuat strategi agar produknya tidak kalah dengan 
pesaing, salah satunya adalah dengan deversifikasi produk. Menurut Nurjanah (Wawancara 22 Februari 2018) salah satu pengerajin keripik tempe, dengan merk dagang Nurdjanah, baru tahun 2005 kebanyakan pengerajin mulai membuat kreasi pilihan rasa keripik tempe aneka rasa agar menarik minat pembeli.

Pada perkembangannya “oleh-oleh makanan" di Kota Malang yang tersedia sekarang bukan merupakan makanan khas yang ada sejak dulu dan mencerminkan budaya makan ataupun gaya hidup masyarakat Kota Malang, namun dianggap khas. Sejak tahun 2014 muncul makanan bernama Strudel, yaitu sejenis kue yang dibuat dari adonan puff pastry. Puff pastry adalah adonan yang terbuat dari tepung terigu berprotein tinggi, air, garam dan mentega, diulen sampai kalis kemudian digiling dan dilipat secara bergantian hingga terbentuk lapisan-lapisan adonan. Salah satu pionir dari inovasi di dunia "oleh-oleh makanan" kekinian Malang adalah Malang Strudel, yang diprakarsai oleh Teuku Wisnu (artis kenamaan Indonesia) yang bekerja sama dengan pengusaha Donny Kris Puryono dan Deni Deliandri. Malang Strudel di klaim dan diberi tagline tau slogan yaitu "“Oleh-Oleh Makanan" Kekinian Khas Malang". Hal tersebut memunculkan tambahan persaingan “oleh-oleh makanan" dimana sekarang tidak hanya sebatas di internal kampung sanan dan produk makanan berupa keripik tempe, selain itu timbul kerancuaan dari makna khas pada "oleh-oleh makanan".

Keberhasilan Malang Strudel menembus pasar "oleh-oleh makanan” di Kota Malang, menimbulkan pro dan kontra. Sebagian menganggap sebagai peluang dan sebagian menganggap sebagai ancaman. Peluang bahwa ada pasar yang menginginkan "oleh-oleh makanan" selain keripik, namun ancaman bagi pengerajin keripik karena ada persaingan produk sehingga wisatawan mempunyai pilihan lain. Hal ini dibenarkan oleh salah satu pengerajin keripik tempe dan anggota Pokdarwis serta paguyuban pedagang Kampung Sanan yang tidak bersedia disebutkan namanya bahwa setelah adanya "oleh-oleh makanan" kekinian omset penjualan 
menurun, karena pilihan lain (“oleh-oleh makanan” kekinian misalnya strudel). Jumlah produksinya menurun hampir 30\% kurang lebih, dari 3 tempat produksinya saya salah satu terpaksa berhenti beroprasi (Wawancara 6 April 2018). Pernyataan tersebut cenderung menuding produk baru yang ada dipasaran sebagai ancaman dan menurunnya jumlah penjualan. Senada tapi tak sama dengan pernyataan sebelumnya, Ketua Pokdarwis Kampung Sanan Lilik Suprapti menyampaikan bahwa dampak adanya "oleh-oleh makanan" kekinian memang dirasa cukup menguncang pengerajin keripik tempe yang ada di Sanan. Namun sebenarnya tidak dapat disalahkan, karena dalam dunia usaha persaingan adalah hal yang biasa. Sebagai produsen harusnya lebih memikirkan bagaimana agar produk kita tidak kalah dengan produk pesaing (Wawancara 17 Maret 2018).

Salah satu "oleh-oleh makanan" kekinian adalah Malang Strudel yang sejak resmi beroprasi pada tanggal 24 Desember 2014 berkembang dengan pesat, buktinya dalam tahun pertama ada lima outlet yang tersebar di Kota Malang (Wisnu, 2016). Kesuksesan Malang Strudel pada perkembangannya menjadi panutan bagi masyarakat lokal maupun pengusaha untuk membuat usaha serupa dalam kurun waktu 4 tahun, mulai dari tahun 2014 hingga kini 2018. Muncul usaha sejenis, baik dengan produk yang sama maupun tidak. Appel Strudel salah satunya adalah salah satu usaha milik masyarakat lokal yang menjual produk yang sama dengan Malang Strudel, artis kenamaan seperti Farah Quinn juga membuka usaha dan menawarkan produk yang sama yaitu Queen strudel. Dapat dilihat pada Gambar 1 berikut tiga produk strudel dengan isian apel yang terkenal di Kota Malang. 




Gambar 1. Tiga Produk Strudel dengan Isian Apel Yang Terkenal Di Kota Malang Sumber: Google Image, 2018

Jenis produk kedua yang berkembang pesat sebagai "oleh-oleh makanan" Kota Malang adalah bolu atau cake, sama halnya dengan strudel ada beberapa yang dimiliki oleh artis Ibu Kota diantaranya Makobu Cake milik Krisdayanti, dan Asix milik Anang. "oleh-oleh" berupa bolu milik masyarakat lokal yang terkenal adalah Spikoe Hana milik Tan Siem Nio, Lapis Malang milik Tika, dan Lapis Tugu Malang milik Prayogo Danardono.

Hal tersebut menunjukkan bahwa memang usaha "oleh-oleh makanan" memang sedang berkembang. Fenomena dinamika perkembangan "oleh-oleh" di Kota Malang dengan segala pro dan kontranya, berdasarkan hasil penelitian banyak ditemukan diberitakan media masa. Media masa yang melaporkan tentang fenomena ini, diantaranya Malang Post dan Malang Times. Dalam artikel "Kue Artis Rajai Pasar Malang Raya" pada website Malang Post (2018), diberitakan terjadi fenomena revolusi bisnis kue artis yang merajai pasar “oleh-oleh” di Kota Malang dan merebut antusias publik. Ribuan box terjual sebagaimana penuturan Tri Maria Ulfa selaku Manager Marketing Malang Strudel, Prastowo Setijabudi selaku direktur marketing Queen Apple dan Ryo Hadi Souji selaku Marketing Communication Asix "oleh-oleh". Dalam berita tersebut Ulfa, Souji dan Setijabudi senada menuturkan tudingan penjualan "oleh-oleh makanan" kekinian milik artis menggangu "oleh- 
oleh makanan" yang diproduksi usaha masyarakat lokal yang kebanyakan usaha kecil menengah (UKM) adalah tidak benar. Perusahaan milik artis mempunyai kebijakan bekerjasama dengan UKM, dengan menyediakan stan untuk produk UKM, namun tetap ada pembinaan dan standarisasi produk bagaimana yang layak dijual di tempat mereka.

Berdasarkan pengamatan peneliti memang ada produk masyarakat lokal yang dijual di outlet oleh-oleh artis, setelah dilakukan penelitian, hasilnya bahwa sistem kerjasama yang digunakan oleh usaha milik artis dengan usaha milik masyarakat lokal adalah sistem konsinyasi atau sistem titip jual dimana pihak yang dititipi baru membayar sebanyak yang terjual. Menurut hasil wawancara dengan salah satu masayarakat lokal pemilik usaha "oleh-oleh makanan" yang menitipkan produknya ke salah satu outlet milik artis, menyatakan bahwa sistem ini tidak sepenuhnya menguntungkan. Berikut kutipan wawancara dengan Helmi produsen keripik tempe bahwa konsinyasi tidak selalu menguntungkan, harga yang cenderung lebih mahal daripada harga pasaran membuat pembeli membeli lebih sedikit, akibatnya stok di outlet yang dititipi menumpuk. Stok yang sudah lama atau sudah rusak harus kita tukar baru. Hal tersebut juga menjadi salah satu kerugian bagi kami (Wawancara, 15 Mei 2018). Berdasarkan permasalahan yang dialami masyarakat lokal sebagai produsen "oleh-oleh makanan", sebaiknya ditanggapi oleh pemerintah dengan membuat kebijakan yang baik dan lebih mendukung mereka.

Pemerintah Kota Malang untuk mendukung produsen "oleh-oleh makanan" sebagai pelaku usaha melalui 3 dinasnya yaitu Dinas Kebudayaan dan Pariwisata, Dinas Koperasi dan UMKM, dan Dinas Perindustrian sebenarnya sudah mempunyai kebijakan, misalnya menyelenggarakan dan mengajak pameran baik yang diselenggarakan di dalam kota maupun luar Kota Malang, memfasilitasi pembinaan, dan permodalan. Selain itu Dinas Kebudayaan dan Pariwisata Kota Malang sejak Maret 2017 mengembangkan aplikasi promosi pariwisata pada 
platform android. Malang Menyapa adalah nama aplikasi tersebut, berikut pada Gambar 2 dapat dilihat tampilan aplikasi Malang Menyapa.

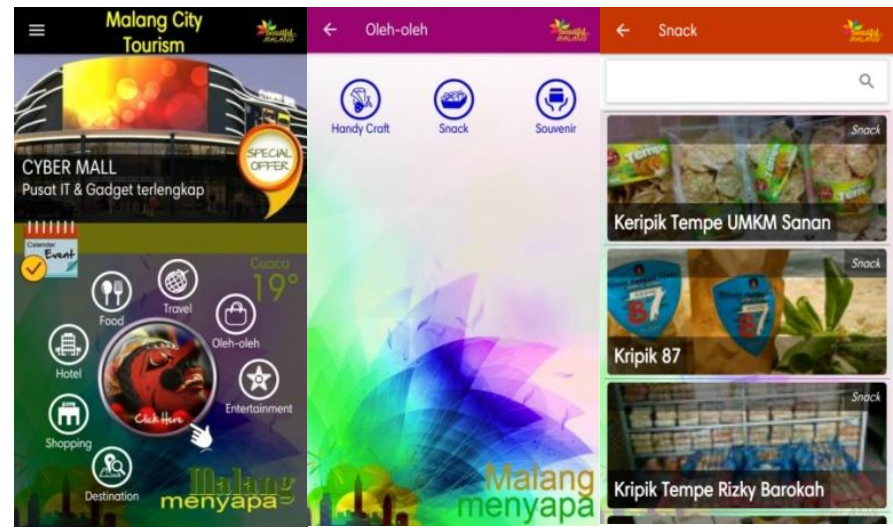

Gambar 2 Tampilan aplikasi Malang Menyapa

Sumber: Survey Peneliti, 2018

Pada Gambar 2 sebelah kiri adalah tampilan awal aplikasi setelah diklik, terdapat 7 menu informasi yang dapat dipilih, menariknya "oleh-oleh" merupakan salah satu menu pilihan. Hal tersebut menandakan bahwa Dinas Kebudayaan dan Pariwisata selaku penggagas aplikasi sadar bahwa "oleh-oleh" merupakan hal yang penting. Tampilan gambar tengah merupakan tampilan aplikasi setelah menu "oleholeh" diklik atau dipilih. Terlihat ada 3 klasifikasi "oleh-oleh" yaitu handy craft, snack dan souvenir. Dapat disimpulkan pada aplikasi ini "oleh-oleh makanan" disebut sebagai snack. Tampilan paling kanan adalah tampilan setelah menu snack pada tampilan tengah sebelumnya diklik. Berdasarkan pengamatan, aplikasi ini masih perlu diperbaiki, salah satu hal yang dapat dilakukan adalah mengelompokkan “oleh-oleh makanan" berdasarkan jenisnya.

Andil Dinas Perindustrian menurut Kepala Seksi Pembinaan dan Pengembangan Industri Makanan dan Minuman Suswati, adalah menyediakan fasilitas promosi melalui pameran yang diadakan Dinas Perindustrian, pelatihanpelatihan untuk menambah pengetahuan, penyediaan dan pemberian informasi tentang permodalan. Menurut Suswati, walaupun telah disediakan fasilitas pada 
kenyataanya banyak juga pelaku usaha yang menolak, karena alasan macam-macam salah satunya takut dipungut biaya padahal setiap kegiatan yang diadakan Dinas Peindustrian adalah gratis. Suswati juga berharap, timbul kesadaran produsen “oleh-oleh makanan” untuk melengkapi legalitas produk yang dijualnya, agar tidak kalah saing. Legalitas yang dimaksud adalah Sertifikat Pirt bagi industri skala rumah tangga, Sertifikat Halal (Wawancara 15 Maret 2018). Legalitas seperti Sertifikat PIRT dapat mengindikasikan bahwa produk layak konsumsi, untuk mendapatkan sertifikat tersebut pelaku usaha dapat mendaftarkan diri ke Dinas Kesehatan Kota Malang untuk diproses sesuai prosedur, layanan ini tidak dipungut biaya. Sertifikat Halal juga mengindikasikan bahwa makanan tersebut layak dikonsumsi oleh golongan tertentu yang mempersyaratkan tidak ada bahan haram yang terkandung didalam makanan tersebut. Untuk mendapatkan sertifikat halal, pelaku usaha dapat mendaftar ke MUI Kota Malang untuk diproses secara lanjut hingga dikeluarkanya sertifikat pernyataan halal.

Menurut penuturan Wahyu Widodo Kepala Bidang Usaha Mikro Dinas Koperasi dan UKM Kota Malang, juga memfasilitasi pelaku usaha “oleh-oleh makanan" lokal, dengan cara menggelar pameran dan bantuan permodalan. Kedepannya Dinas Koperasi dan UKM juga mempunyai program untuk mendukung produk UKM yang termasuk “oleh-oleh makanan” juga, di tahun 2019 akan dibuat tempat one stop shopping, dimana pengunjung terutama wisatawan dapat berbelanja produk buatan UKM Kota Malang termasuk “oleh-oleh". Untuk bantuan permodalan memang ada dana bergulir, UKM ingin mendapat bantuan diharapkan membuat proposal, selanjutnya akan dipilih mana UKM yang berhak karena dana tersebut juga terbatas (Wawancara 15 Maret 2018). Berdasarkan hasil penelitian, bantuan promosi oleh Dinas Perindustrian dan Dinas Koperasi dan UKM tidak sebatas pada event pameran besar. Buktinya pada kedua kantor tersebut terdapat produk "oleh-oleh makanan" buatan masyarakat lokal Kota Malang yang 
mereka bina. Pada Gambar 3 berikut dapat dilihat lemari kaca berisi produk "oleholeh makanan” Kota Malang di Kantor Dinas Perindustrian.

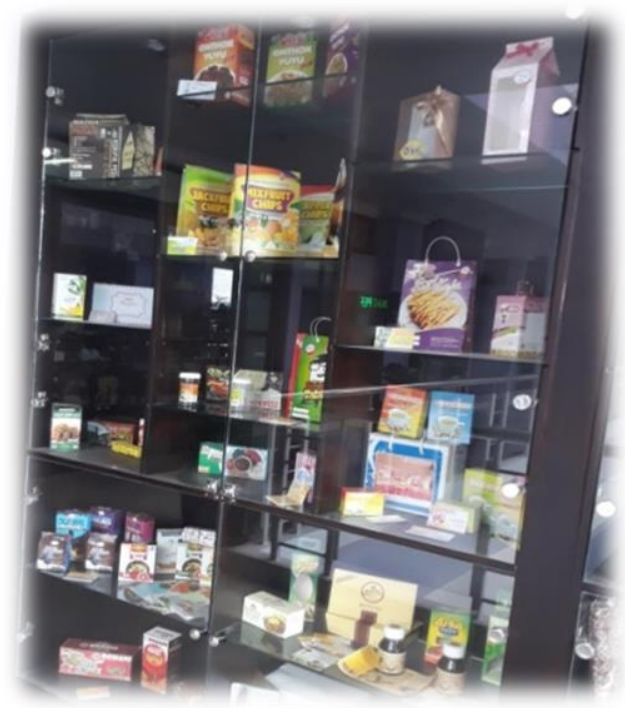

Gambar 3 Tempat Pameran Di Kantor Dinas Perindustrian Kota Malang Sumber: Survey Peneliti, 2018

Dinas Koperasi dan UKM Kota Malang, juga mempunyai tempat untuk memamerkan produk UKM termasuk “oleh-oleh makanan” Kota Malang. Bedanya adalah di dinas ini pengunjung dapat membeli produk yang dipamerkan. Berikut Pada Gambar 4 dapat dilihat di tempat pameran dan penjualan Produk "oleh-oleh makanan" Kota Malang Di Kantor Dinas Koperasi dan UKM Kota Malang.
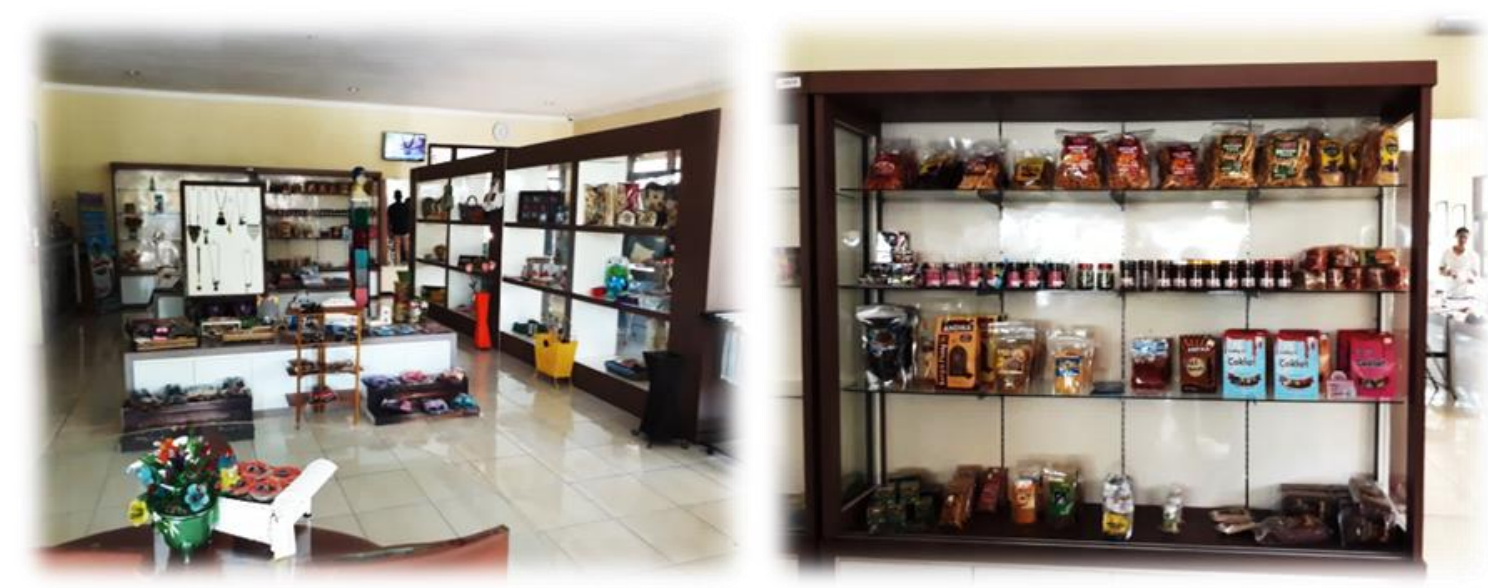

Gambar 4 Tempat Pameran dan Penjualan Di Kantor Dinas Koperasi dan UKM Kota Malang Sumber: Survey Peneliti, 2018. 
Keterlibatan Dinas Industri dan Dinas Koperasi dan UKM, dalam mendukung perkembangan wisata belanja "oleh-oleh makanan" kedepannya memang penting, hal ini mengingat pariwisata merupakan multi sektor yang terlibat. Dalam Renstra Disbudpar 2013 disebutkan, Kota Malang memiliki pola pertumbuhan industri yang unik, dimana sebagian besar industrinya disokong oleh sektor industri kecil dan mikro. Industri mikro yang terbesar adalah sektor industri gastronomi olahan holtikultura berupa makanan ringan oleh-oleh khas daerah, yang keberadaannya sangat menunjang sektor pariwisata. Keberadaan industri "oleholeh makanan" ini tentu menambah potensi ekonomi di Kota Malang.

Sampai saat ini memang belum ada laporan khusus mengenai berapa jumlah yang dapat disumbangkan sektor ini terhadap pendapatan asli daerah, namun secara kasar dapat digambarkan dari data yang didapat dari Dinas Perindustrian Kota Malang mengenai potensi sentra pada bidang usaha tempe kedelai dan keripik tempe tahun 2017 di Kota Malang nilai investasi mencapai Rp 52.738.639,07, dengan daya serap tenaga kerja 1384 orang, kedua jumlah tersebut merupakan nilai tertinggi dibanding nilai pada bidang usaha lainnya. Hal ini berarti bidang usaha tempe kedelai dan keripik tempe sebagai berprospek baik dalam mendorong pertumbuhan ekonomi dan penerimaan PAD. Berdasarkan paparan mengenai perkembangan wisata belanja "oleh-oleh makanan di Kota Malang, maka dapat dibuat tabel periodeisasi untuk meringkas informasi agar lebih mudah dipahami, sebagaimana dapat dilihat pada Tabel 1 berikut. 
Tabel 1

Perkembangan Wisata Belanja “Oleh-Oleh Makanan” di Kota Malang

\begin{tabular}{|c|c|c|}
\hline Fase & Tahun & Momentum \\
\hline Awal & $\begin{array}{l}1980- \\
1989\end{array}$ & $\begin{array}{l}\text { Timbul inisiatif masyarakat mengolah potensi bahan makanan } \\
\text { lokal di Kota Malang, salah satunya yaitu tempe menjadi produk } \\
\text { jadi yang lebih awet dan tahan lama menjadi olahan keripik } \\
\text { tempe. }\end{array}$ \\
\hline Tengah & $\begin{array}{l}1990- \\
2013\end{array}$ & $\begin{array}{l}\text { Bertambahnya jumlah pengerajin keripik tempe, sehingga } \\
\text { muncul persaingan antar produsen dengan produk yang sama, } \\
\text { kemudian muncul kreasi penambahan bumbu perasa ke keripik } \\
\text { tempe, selain itu muncul jenis "oleh-oleh makanan" lainnya yaitu } \\
\text { keripik buah apel. Produsen dari oleh-oleh makanan" merupakan } \\
\text { masyarakat lokal dan skala usaha mereka masih dalam level } \\
\text { mikro hingga menengah. }\end{array}$ \\
\hline Akhir & $\begin{array}{l}2014- \\
2018\end{array}$ & $\begin{array}{l}\text { Masuknya pengusaha dengan modal besar dan strategi } \\
\text { pemasaran yang bagus dengan menawarkan jenis makanan yang } \\
\text { baru dan bekerjasama dengan artis untuk membranding } \\
\text { produknya, produk mereka kemudian disebut sebagai "oleh-oleh } \\
\text { makanan kekinian". Hingga pertengahan } 2018 \text { sudah ada } 5 \\
\text { produsen "oleh-oleh makanan kekinian". }\end{array}$ \\
\hline
\end{tabular}

Sumber: Hasil Penelitian, 2018.

Ragam makanan yang dijadikan "oleh-oleh makanan" bertambah, jika dulu Kota Malang hanya terkenal akan apel dan keripik tempe. Saat ini bermunculan jenis makanan lain yang menjadi “oleh-oleh makanan”. "Oleh-oleh makanan” yang baru muncul dijuluki sebagai "oleh-oleh makanan" kekinian. Saat ini setidaknya ada sembilan jenis makanan yang populer sebagai "oleh-oleh makanan" khususnya di Kota Malang. Pada tabel 2 berikut dapat dilihat "oleh-oleh makanan" di Kota Malang berdasarkan jenisnya. 
Tabel 2.

Jenis “Oleh-Oleh Makanan” Kota Malang

\begin{tabular}{|c|c|c|c|}
\hline No & Jenis Makanan & Deskripsi & $\begin{array}{c}\text { Contoh Merk } \\
\text { Terpopuler }\end{array}$ \\
\hline 1 & Apel & $\begin{array}{l}\text { Buah, berbentuk bulat tidak sempurna, } \\
\text { kulitnya berwarna merah, atau hijau. } \\
\text { Dagingnya berwarna putih kekuningan. }\end{array}$ & $\begin{array}{l}\text { Manalagi, Anna, } \\
\text { Romebeauty }\end{array}$ \\
\hline 2 & Bakso Beku & $\begin{array}{l}\text { Makanan yang terbuat dari daging yang } \\
\text { dihaluskan dengan cara digiling, kemudian } \\
\text { diberi bumbu dan dimasak menggunakan } \\
\text { teknik rebus, setelah itu diawetkan dengan } \\
\text { cara dibekukan. }\end{array}$ & $\begin{array}{l}\text { Bakso Damas, } \\
\text { Bakso President }\end{array}$ \\
\hline 3 & Bolu & $\begin{array}{l}\text { Makanan kue yang terbuat dari tepung } \\
\text { terigu protein sedang, telur, gula, yang } \\
\text { dimasak dengan cara dikukus atau dioven, } \\
\text { kemudian diberi atasan atau isian. }\end{array}$ & $\begin{array}{lr}\text { Asix, } & \text { Makobu } \\
\text { Cake, } & \text { Lapis } \\
\text { Malang, } & \text { Lapis } \\
\text { Tugu } & \\
\end{array}$ \\
\hline 4 & Coklat & $\begin{array}{l}\text { Makanan terbuat dari biji kakao, dimasak } \\
\text { dengan cara ditim dan dicampur atau diisi } \\
\text { dengan bahan lain ketika dicetak. }\end{array}$ & $\begin{array}{l}\text { De Konco Coklat } \\
\text { Tempe }\end{array}$ \\
\hline 5 & Keripik Buah & $\begin{array}{l}\text { Makanan yang terbuat dari buah yang } \\
\text { dimasak menggunakan teknik goreng. }\end{array}$ & So Kressh \\
\hline 6 & Keripik Tempe & $\begin{array}{l}\text { Makanan yang terbuat dari tempe dan } \\
\text { tepung beras yang diberi bumbu dan } \\
\text { kemudian dimasak menggunakan teknik } \\
\text { goreng. }\end{array}$ & $\begin{array}{l}\text { Rohani, Nurjanah, } \\
\text { Lancar Jaya, } \\
\text { Swari, Ini Keripik }\end{array}$ \\
\hline 7 & Pie & $\begin{array}{l}\text { Makanan yang terbuat dari tepung terigu } \\
\text { protein rendah, margarin atau mentega, } \\
\text { telur, dan garam, yang kemudian dibentuk } \\
\text { dan diberi isian. Lalu dimasak } \\
\text { menggunakan teknik oven. }\end{array}$ & Pie Apel Malang \\
\hline 8 & Bakpia/Pia & $\begin{array}{l}\text { Makanan yang terbuat dari tepung terigu } \\
\text { protein tinggi, margarin, yang kemudian } \\
\text { diisi dengan isian lalu di masak dengan cara } \\
\text { dioven. }\end{array}$ & $\begin{array}{l}\text { Pia Cap Mangkok, } \\
\text { Pia Matahari }\end{array}$ \\
\hline 9 & Strudel & $\begin{array}{l}\text { Makanan yang terbuat dari tepung terigu } \\
\text { protein tinggi, margarin, diolah } \\
\text { menggunakan teknik khusus agar berlapis } \\
\text { lapis, kemudian diisi dengan isian lalu di } \\
\text { masak dengan cara dioven. }\end{array}$ & $\begin{array}{l}\text { Malang Strudel, } \\
\text { Queen Appel, Apple } \\
\text { Strudel }\end{array}$ \\
\hline
\end{tabular}

Sumber: Hasil Penelitian, 2018 
Berikut pada Gambar 5 dapat dilihat beberapa produk "oleh-oleh makanan” yang ada di Kota Malang.

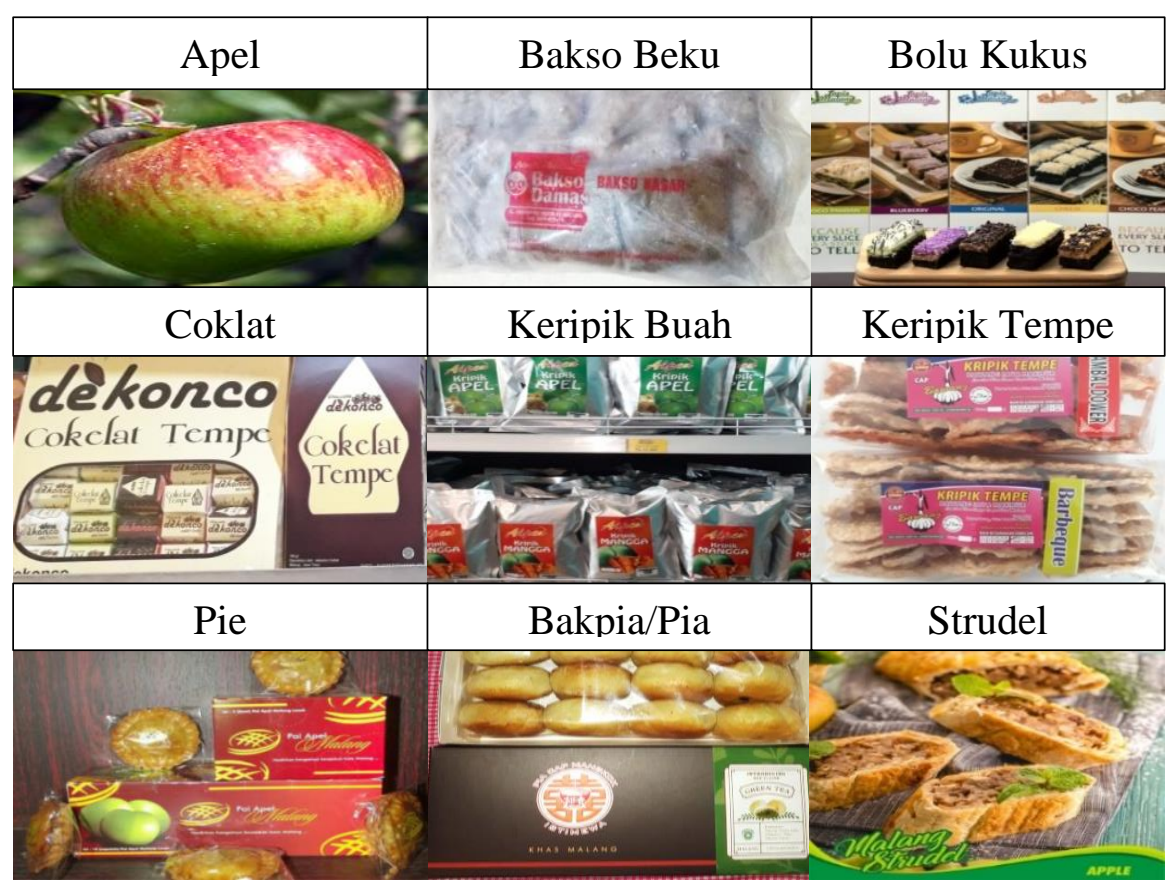

Gambar 5. Foto beberapa produk "oleh-oleh makanan" yang ada di Kota Malang Sumber: Dokumentasi Peneliti dan Google Image 2018.

Menurut Buczkowska (2014) jenis "oleh-oleh makanan" tergantung potensi komoditi yang ada di destinasi, misalnya di Polandia yang terpopuler adalah sweets, alcohols, spices, ect., sehingga dapat disimpukan bahwa potensi makanan yang dapat dijadikan "oleh-oleh" tergantung pada kearifan lokal yang ada di suatu destinasi. Selanjutnya, untuk mendapatkan produk "oleh-oleh makanan" di Kota Malang wisatawan kebanyakan langsung mengunjungi dan membeli ke sentra penjualan yang mempunyai reputasi ataupun merk yang baik atau terkenal, berdasarkan hasil penelitian dapat dilihat daftar beberapa sentra atau pusat penjualan "oleh-oleh makanan" di Kota Malang pada Tabel 3 berikut. 
Tabel 3

Daftar Sentra Penjualan “Oleh-Oleh Makanan” di Kota Malang

\begin{tabular}{|c|c|c|}
\hline No & Sentra & Alamat \\
\hline 1 & Kampung Sanan & 1. Jl. Sunandar Prio Sudarmo \\
\hline 2 & Goedang Oleh-Oleh Malang & 1. Jl. Simpang Tenaga II no. 12 \\
\hline 3 & Ini Keripik & $\begin{array}{l}\text { 1. Jl. Sukarno hatta Blok } 32 \\
\text { 2. Jl. Kawi Atas No.23 Malang }\end{array}$ \\
\hline 4 & Malang Strudel & $\begin{array}{l}\text { 1. Jl. WR Supratman C3/24 } \\
\text { 2. Jl. Soekarno Hatta } 2 \text { kav } 6 \\
\text { 3. Jl. Semeru No. } 47 \\
\text { 4. Jl. Soekarno Hatta Kav.D } 408\end{array}$ \\
\hline 5 & Queen Apple & 1. Jl. Kawi Atas No.23 \\
\hline 6 & Apple Strudel & $\begin{array}{l}\text { 1. Jl. Borobudur No. } 22 \\
\text { 2. Jl. K.H. Hasyim Ashari No. } 6 \\
\text { 3. Jl. S. Supriadi No. 59B } \\
\text { 4. Jl. Raya Tlogomas, Komplek Pom Bensin }\end{array}$ \\
\hline 7 & Pai Apel Malang & 1. Jl. R. Tumenggung Suryo No.90B \\
\hline 8 & Makobu Cake & 1. Jl. Ijen No.82 \\
\hline 9 & Lapis Malang & $\begin{array}{l}\text { 1. Jl. Soekarno Hatta Kav. } 5 \text { No. } 30 \\
\text { 2. Jl. Kawi Atas No. } 43 \text { c }\end{array}$ \\
\hline 10 & Lapis Tugu Malang & $\begin{array}{l}\text { 1. Jl. Soekarno Hatta } 30 \text { kav } 8 \\
\text { 2. Jl. Laksda Adi Sucipto No.60 } \\
\text { 3. Jl. Raya Tlogomas } 37 \mathrm{D} \text { Malang } \\
\text { 4. Jl. Temenggung Suryo 21A Sanan } \\
\text { 5. Jl. Danau Toba E5 } 12 \text { Kav } 5 \text { Sawojajar }\end{array}$ \\
\hline 11 & A6 Oleh-Oleh & 1. Jl. Guntur No.8 \\
\hline 12 & So Kressh & 1. Jl. Polowijen Gang 3 \\
\hline 13 & Pia Mangkok & $\begin{array}{l}\text { 1. Jl. Semeru No. } 25 \\
\text { 2. Jl. Villa Tidar Indah No.5 } \\
\text { 3. Jl. Sukarno Hatta Kav. 16-17 }\end{array}$ \\
\hline 14 & De Konco Coklat & $\begin{array}{l}\text { 1. Jl. Danau Kerinci Raya No.Kav } 9 \text { No 13- } \\
14\end{array}$ \\
\hline 15 & Spikoe Hana & 1. Jl. R. Tumenggung Suryo No.28, B \\
\hline
\end{tabular}

Sumber: Hasil Penelitian, 2018 dan Lapkir Dinas Pariwisata, 2017 
Dari beberapa sentra yang disebutkan pada Tabel 3 terdapat satu sentra yang menjadi unggulan di Kota Malang dan diunggulkan oleh pemerintah Kota Malang khususnya dinas kebudayaan dan pariwisata yaitu Kampung Sanan sebagaimana disebutkan dalam laporan kinerja dinas tersebut, menurut Ketua Pokdarwis Pengerajin Keripik Tempe Kampung Sanan terdapat 55 pengerajin yang juga penjual keripik tempe. Dalam laporan dinas kebudayaan dan pariwisata Kampung Sanan dimasukkan kedalam wisata kampung tematik, karena merupakan pusat produksi keripik tempe "oleh-oleh" khas Kota Malang.

Sentra "oleh-oleh makanan" Kampung Sanan, merupakan sebuah kampung yang sebagian besar warganya membuat dan menjual keripik tempe serta "oleh-oleh makanan" Kota Malang. Pengelompokan Kampung Sanan sebagai wisata tematik rasanya kurang tepat menurut amatan peneliti. Kampung Sanan lebih cocok dijadikan destinasi wisata belanja berbasis kuliner. Kelebihan Kampung Sanan dibandingkan sentra belanja yang lain adalah wisatawan mendapatkan stok produk yang baru dibuat dan bisa melihat proses pembuatan keripik tempe yang mereka beli. Pada Gambar 6 berikut dapat dilihat proses pembuatan keripik tempe di salah satu tempat produksi sekaligus penjualan keripik tempe di keripik tempe merk Rohani.

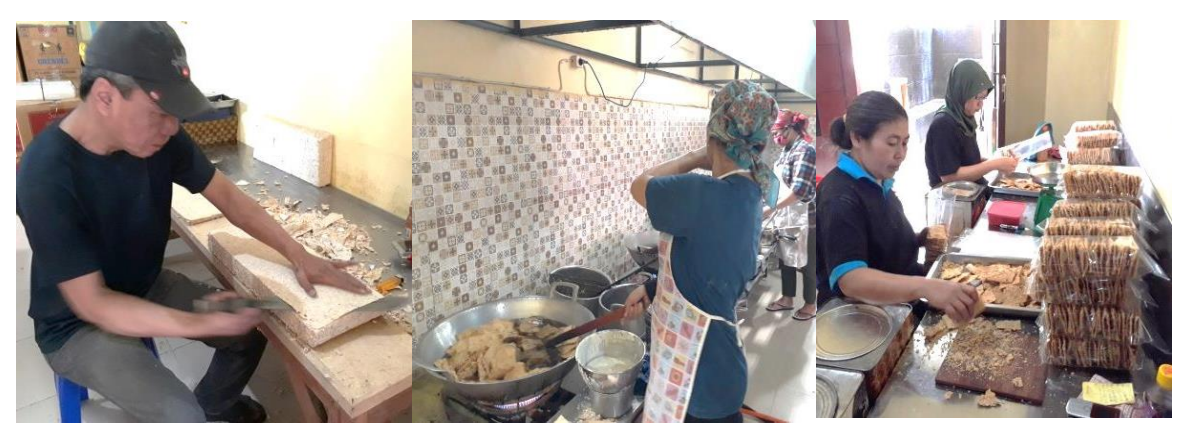

Gambar 6. Proses Produksi Keripik Tempe yang bisa dilihat Wisatawan Sumber: Survey Peneliti (2018) 


\section{Simpulan dan Saran}

Berdasarkan analisis yang dilakukan simpulan yang dapat diberikan yaitu, perkembangan wisata belanja "oleh-oleh makanan" didukung perkembangan industri mikro gastronomi dan adanya minat wisatawan terhadap "oleh-oleh makanan". Awalnya "oleh-oleh makanan" dari Kota Malang terbatas pada apel dan keripik tempe, untuk mendapatkan keripik tempe wisatawan dapat mengunjungi sentra penjualan yang diunggulkan pemerintah yaitu Kampung Sanan. Saat ini dengan adanya perkembangan wisata belanja "oleh-oleh makanan" secara pesat dalam kurun waktu empat tahun yaitu mulai tahun 2014-2018, saat ini "oleh-oleh makanan" diketahui ada 9 jenis yaitu apel, bakso beku, bolu, coklat, keripik buah, keripik tempe, pie, bakpia/pia, dan strudel.

Kemunculan beberapa jenis makanan baru seperti strudel yang dilabeli sebagai "oleh-oleh makanan" kekinian, menimbulkan pro dan kontra di masyarakat yang mempunyai usaha "oleh-oleh makanan". Beragamnya produk dianggap menjadi ancaman karena keadaan pasar berubah sehingga terjadi penurunan penjualan karena ada penurunan permintaan, terutama pada jenis "oleh-oleh makanan" terdahulu yaitu keripik tempe. Pemerintah sebenarnya sudah berupaya untuk meminimalisir masalah yang timbul dengan membantu dan mendampingi masyarakat lokal yang mempunyai usaha "oleh-oleh makanan", akan tetapi pelaksanaanya memang belum maksimal karena ada kendala salah satunya komunikasi dan motivasi mereka sendiri untuk memperbaiki dan mengembangkan produk mereka agar tidak kalah saing di pasaran.

Adapun saran yang dapat disampaikan adalah sebagai berikut: (1) untuk pemerintah, perlu meningkatkan sosialisasi mengenai fasilitas yang dapat diberikan kepada masyarakat selaku pelaku usaha dibidang "oleh-oleh makanan", dengan cara membuat pengumuman di tempat terbuka misalnya memasang baliho di jalan tentang penyelenggaraan sosialisasi. (2) bagi pelaku usaha "oleh-oleh makanan", 
hendaknya rajin mencari informasi, mengikuti pelatihan untuk meningkatkan pengetahuan dan ilmu usaha, serta berupaya mempertahankan kualitas produknya. Selain itu sebaiknya para produsen makanan lokal segera mengurus legalitas seperti sertifikasi halal, PIRT, daftar merk untuk produknya, tujuannya adalah untuk menambah kepercayaan konsumen dalam proses memilih dan membeli "oleh-oleh makanan". (3) untuk peneliti selanjutnya, para peneliti yang ingin melakukan penelitian di Kota Malang dapat melakukan penelitian yang lebih mendalam mengenai impilkasi dan dampak wisata belanja "oleh-oleh makanan" terhadap perekonomian Kota Malang.

\section{Daftar Pustaka}

Hasan, Ali. 2015. Tourism Marketing. Yogyakarta: CAPS (Center for Academic Publishing Service). Yogyakarta: Kanisius.

Hapiz, T.M., 2015. “Hubungan Tingkat Modal Sosial Terhadap Tingkat Pendapatan Pelaku UKM". Jurnal Mahasiswa Sosiologi, 3(2).

Laporan Kinerja Dinas Kebudayaan dan Pariwisata Kota Malang. 2017. Penyusunan Survey Data Pariwisata Kota Malang Tahun 2017. Malang: tidak diterbitkan.

Malangkota. 2018. "Tri Bina Cita", sumber: https://malangkota.go.id/sekilasmalang/tri-bina- cita/.

Malang Post. 2018. "Kue Artis Rajai Pasar Malang Raya", sumber: (https://www.malang-post.com/lapsus/kue-artis-rajai-pasar-malang-raya), Diakses 13/04/2018.

Mossberg, L. 2007. “A Marketing Approach to The Tourist Experience. Scandinavian Journal of Hospitality and Tourism, 7(1), pp.59-74.

Pedoman Pokdarwis. 2012. Sumber:

http://www.kemenpar.go.id/userfiles/1_\%20Pedoman\%20Pokdarwis.pdf

Peluang Usaha. 2010. “ Metamorfosis Sebuah Sentra Keripik Tempe”, sumber:

http://peluangusaha.kontan.co.id/news/metamorfosis-sebuah-sentra-keripiktempe. Diakses: 14/8/2018

Peraturan Wali Kota (PERWALI) Nomor 34 Tahun 2014 tentang Rencana Induk Pengembangan Pariwisata Daerah (RIPPD) Kota Malang Tahun 2014-2025. Sumber: https://kotamalang.jdih.jatimprov.go.id/?wpfb_dl=46. 
Putra, I.N.D., 2014. “Empat Srikandi Kuliner Bali: Peran Perempuan dalam Pembangunan Pariwisata Berkelanjutan 1". Jurnal Master Pariwisata (Journal Master in Tourism Studies), 1(1).

Rencana Strategis (renstra) Dinas Kebudayaan dan Pariwisata Kota Malang 20132018

Timothy, D.J., 2005. “Shopping Tourism, Retailing, and Leisure (Vol. 23)”. Channel View Publications.

Widyasari, W.W. and Manzilati, A., 2012. Identifikasi Struktur Pasar Dan Implikasinya Terhadap Pembentukan Harga (Studi Kasus Pada Sentra Industri Keripik Tempe Sanan Malang). Jurnal Ilmiah Mahasiswa FEB, $1(1)$.

Wilkins, H. 2011. "Souvenirs: What and Why We Buy". Journal of Travel Research, 50(3), p, 239.

\section{Profil Penulis}

Nonny Aji Sunaryo, S.Pd., M.Par., merupakan alumnus S1 Pendidikan Tata Boga Universitas Negeri Malang, dan S2 Magister Pariwisata Universitas Udayana Denpasar 2018. Semasa studi magister beliau menerima Beasiswa Unggulan Masyarakat Berprestasi dari Kementerian Pendidikan dan Kebudayaan Indonesia. Lulus dari studi magister tahun 2018 beliau bekerja sebagai dosen luar biasa di Pendidikan Vokasi Manajemen Perhotelan Universitas Brawijaya Malang, pada 2019 beliau mulai bekerja sebagai Dosen CPNS di Prodi Teknologi Industri Fakultas Teknik Universitas Negeri Malang. Bidang keahlian yang diminati dan ditekuni adalah pendidikan, kewirausahaan, kuliner, dan pariwisata. Email: nonny.sunaryo.ft@um.ac.id

Prof. Dr. I Nyoman Darma Putra, M.Litt., merupakan alumnus S1 Sastra Indonesia Universitas Udayana, S2 University of Sydney, dan S3 The University of Queensland. Selain sebagai dosen di Fakultas Ilmu Budaya Unud, beliau aktif mengajar di Prodi S2 dan S3 Fakultas Pariwisata Udayana. Bidang keahlian yang 
beliau minati dan tekuni adalah pariwisata budaya, heritage tourism, pariwisata dan media. Email: idarmaputra@yahoo.com

Dr. Made Heny Urmila Dewi, SE., M.Si., merupakan alumnus S1 Manajemen UNUD, S2 Kependudukan dan Pengembangan Sumber Daya UGM, S3 Kajian Pariwisata UGM, beliau aktif mengajar di Prodi S2 Pariwisata UNUD. Bidang keahlian yang beliau minati dan tekuni adalah kependudukan dan ketenagakerjaan, pengembangan pariwisata, ekonomi pariwisata. Email: henyurmila@gmail.com 